\title{
THE OXIDATION OF ANTHRAQUINONE DYE USING HRP IMMOBILIZED AS A CROSS-LINKED ENZYME AGGREGATES
}

Nataša Ž. Šekuljica ${ }^{1^{\star}}$, Nevena Ž. Prlainović ${ }^{1}$, Andrea B. Stefanović $^{2}$, Jelena R. Jovanović Sonja M. Jakovetić2 ${ }^{2}$ Zorica D. Knežević-Jugović², Dušan Ž. Mijin ${ }^{2}$

(ORIGINAL SCIENTIFIC PAPER) UDC 577.152.3:66.098:667.283.6

1 University of Belgrade, Innovation Center, Faculty of Technology and Metallurgy, Belgrade, Serbia

2 University of Belgrade, Faculty of Technology and Metallurgy, Belgrade, Serbia

Finding a sustainable and ecofriendly methods for recalcitrant synthetic dyes removal is a researchers' major challenge. A carrier-free technique for commercial HRP immobilization is a focus of the present study. The immobilized biocatalyst, HRPCLEAs with $580 \mathrm{U} \mathrm{g}^{-1}$ of the activity was obtained under the following immobilization conditions: precipitation reagent $80 \%$ ammonium sulphate, cross-linking reagent $1 \%$ of glutaraldehyde and protein-fedder, bovine serum albumin (BSA) concentration 5 $\mathrm{mg} \mathrm{ml}^{-1}$. The obtained HRP-CLEAs showed great affinity towards model anthraquinone dye, C. I. Acid Violet 109. 88.4\% of the dye was oxidized under the reaction conditions: $\mathrm{pH} 4$, dye concentration $40 \mathrm{mg} \mathrm{l}^{-1}, \mathrm{H}_{2} \mathrm{O}_{2}$ concentration $1 \mathrm{mM}$ and $0.1 \mathrm{U}$ of HRP-CLEAs. The possibility of the immobilized biocatalyst application in five and eight oxidation cycles of the dye and pyrogallol (retained activity $\sim 80 \%$ ), respectively, indicates that HRP-CLEAs is an efficient and environmentally friendly biocatalyst with great potential in aromatic compounds removal from wastewater. This paper is a continuation of our earlier research related to HRP from horseradish extract immobilization in the form of CLEAs and the application in the wastewater colored with a synthetic anthraquinone dye treatment.

\section{Introduction}

Horseradish peroxidase enzyme (HRP) is a highly specific, efficient and easy available enzyme in a pure form at an affordable price [1]. Due to these properties, it is used in various fields such as: immunodiagnostics, biosensors, immunoassays, organic synthesis, food industry etc. [2-6]. Nowadays, one of the leading problems is a constant water pollution increase and depletion of valuable water resources. The main industrial wastewater problem is the presence of synthetic dyes. Synthetic dyes are recalcitrant pollutants. Due to very large molecular structure and fused aromatic rings in which substitutions with halides $(\mathrm{Cl}, \mathrm{Br})$ are frequent, they are persistent in the environment and resistant to biodegradation [7]. Pollutants in the wastewater and their synergistic effects cause a negative impact on the environment and humans. The toxicity and carcinogenicity are the main features of synthetic dyes. These features lead to the environment pollution, aquatic organisms' growth inhibition and the appearance of human diseases such as skin ulceration, dermatitis, bleeding, nausea or cancer [8-11]. The oxidation of different wastewater pollutants such as phenol, synthetic dyes and pharmaceuticals is a new field of the horseradish peroxidase application interesting for the researchers. The processes of the pollutants oxidation catalyzed by HRP are proved to be efficient and ecologically acceptable [12-14]. The main drawback of HRP application in the pollutants oxidation is instability and sensitivity of the enzyme.

Immobilization is a main technique for the enzyme stability increase. After the immobilization, the increase in stability is followed by the possibility of re-use. Different techniques and supports are applied for obtaining the immobilized HRP with the purpose of the wastewater treatment. The data about HRP immobilization by adsorption, covalent immobilization and entrapment are well documented in literature. Applicative potential of the synthetic dyes treatment by immobilized HRP is great, but considering the fact that a number of newly synthesized dyes is trending upward every day, findings of new immobilized HRP preparations is of vital importance for their removal from wastewaters. For example, HRP was immobilized on the kaolin clay via adsorption and applied in the anthraquinone dye oxidation [7]. Aluminum-pillared interlayered clay (AI-PILC) was used for the enzyme-clay complex preparation by the adsorption method [15]. The obtained enzyme-clay complex was used for the treatment of wastewater polluted with phenol. Fumed silica served as the support for the adsorp-

\footnotetext{
*Author address: Nataša Šekuljica, Innovation Center Faculty of Technology and Metallurgy, Karnegijeva 4, 11000 Belgrade, Serbia

E-mail: nsekuljica@tmf.bg.ac.rs

The manuscript received: September, 09, 2016

Paper accepted: October, 17, 2016.
} 
tion of HRP and immobilized biocatalyst was successfully applied in the AV 109 dye removal [16].

Chang et.al used graphene oxide for the magnetic $\mathrm{Fe}_{3} \mathrm{O}_{4}$ nanoparticles deposition [17]. HRP covalently immobilized on the superparamagnetic $\mathrm{Fe}_{3} \mathrm{O}_{4}$ /graphene oxide was used for the chlorophenols removal by the free radical polymerization mechanism. Bonding between HRP and ethyl cellulose particles was achieved by using carbodiimide cross-linker, and by using the obtained immobilized preparation, the outstanding efficiency in the elimination of 2,4-dichlorophenol was confirmed [18]. Eupergit C, microfibrous membranes, phospholipid-templatedtitania, magnetic beads were used for the covalent HRP immobilization, and the immobilized biocatalyst was applied in the phenol removal [19-21]. Besides adsorption and covalent bonding, the HRP immobilization via entrapment in different polymers was performed. $\beta$-cyclodextrin-chitosan complex served for the HRP entrapment and different dyes removal [22]. For the azo dye degradation from the tannery wastewater HRP entrapped in the alginate was applied [23]. As it can be seen, different supports and classic immobilization methods were used for the HRP immobilization.

Carrier-free immobilization methods have attracted great attention recently. The principle of the carrierfree immobilization method is precipitation followed by cross-linking of the formed aggregates. The obtained immobilized preparation does not include the catalytically inactive mass originating from the support used, as in the case of classic immobilization methods. This immobilization technique is simple, inexpensive and crude enzyme extracts without further purification can be the enzyme source for cross-linked enzyme aggregates (CLEAs) preparation, thus the cost of the entire process is significantly reduced [24-26]. Compared to conventional immobilization methods, the main drawback of CLEAs preparation is the lack of a mechanical stability. Besides, low viscosities can cause difficulties during CLEAs recovery at large-scale systems [27]. In recent years, the applicative potential of oxidoreductive enzymes immobilized in the form of CLEAs in the colored wastewater treatment has been examined. Until now, in literature there have been data about lacasse, versatile peroxidase, glucose oxidase and horseradish peroxidase immobilization in the form of CLEAs [28-33]. In our previous study, we examined the immobilization of peroxidase from a fresh horseradish extract in the form of CLEAs, and then the obtained immobilized preparation was applied in the anhraquinone dye oxidation. The resulting immobilized preparation showed great affinity towards the tested dye, high efficiency and the possibility of the application of this preparation in a recycled packed bed reactor was confirmed. By using the unpurified HRP the advantage of this immobilization technique was fully exploited, and the cost of the entire process reduced significantly.

For the purpose of the comparison with peroxidase from fresh horseradish extract CLEAs, this paper fo- cuses on the possibility of the commercial HRP immobilization in the form of cross-linked enzyme aggregates. The optimization of the immobilization procedure was examined in terms of precipitant choice and cross-linking reagent concentration. Besides, the protein feeder addition on the operational stability and the activity of immobilized preparations was examined by using pyrogallol as a substrate. The obtained HRP-CLEAs were applied in the anthraquinone dye C.I. AV 109 oxidation. Parameters influencing a dye oxidation degree catalyzed by HRP-CLEAs: $\mathrm{pH}$, dye and $\mathrm{H} 2 \mathrm{O} 2$ concentrations were evaluated. In addition, the operational stability of immobilized HRP was examined in both, the dye and the pyrogallol oxidation reaction.

\section{Materials and methods}

\section{Materials}

Horseradish enzyme (EC 1.11.1.7), pyrogallol and glutaraldehyde were supplied from Sigma-Aldrich (USA). Anthraquinone dye used in this paper, C. I. Acid Violet 109 (AV 109), was obtained from Lanaset (Lanaset Violet B). Hydrogen peroxide was purchased from E. Merck (Darmstadt), and its concentration was determined several times using molar absorption coefficient $\left(\varepsilon=43.6 \mathrm{M}^{-1} \mathrm{~cm}^{-1}\right)$ at $\lambda=$ $240 \mathrm{~nm}$ by dilution of the supplied $\mathrm{H}_{2} \mathrm{O}_{2}(30 \% \mathrm{v} / \mathrm{v})$ solution. All other chemicals and reagents used in this work were of analytical grade.

\section{Methods}

HRP immobilization protocol optimization

HRP solution $\left(1 \mathrm{mg} \mathrm{m}^{\mathrm{l}-1}\right)$ was prepared in the potassium-phosphate buffer, pH 7, 0,1 M. HRP immobilization in the form of CLEAs was performed in two steps: 1) precipitation and 2) cross-linking. The influence of the precipitating reagent was examined by varying acetone, 2-propanol and ammonium sulphate as precipitation reagent and their influence on the activity recovery and aggregation yield was followed.

The immobilization mixture, enzyme and the precipitant $(1: 3 \mathrm{v} / \mathrm{v})$, was gently mixed at $4{ }^{\circ} \mathrm{C}, 45 \mathrm{~min}$ after adding the precipitating reagent. After the precipitating step, the cross-linking reagent, glutaraldehyde solution (25\%) was added in the immobilization mixture until the final concentration of 0,$5 ; 0,75 ; 1 ; 1,5$ i $2 \%$ was reached. The immobilization was allowed to continue for $3 \mathrm{~h}$ at $4{ }^{\circ} \mathrm{C}$, under constant agitation (150 rpm). Enzymes with low Lys content cannot be cross-linked in the form of stable aggregates. Therefore, inert proteins such as BSA are often added to the reaction mixture in order to enrich it with free amino groups capable for Schiff base formation with glutaraldehyde. For that reason, the BSA was added $(1,5,10 \mathrm{mg})$ and the activity recovery and aggregation yield were calculated. The immobilization efficiency was characterized using two parameters [31]:

$$
\begin{aligned}
& \text { Activity recovery, } \%=\frac{\text { Total activity of HRP }-C L E A s}{\text { Total activity of HRP used for CLEAs production }} \times 100 \ldots \\
& \text { Aggregation yield, } \%=\left[1-\frac{\text { Protein content in supernatant }(\mathrm{mg})}{\text { Offered protein amount }(\mathrm{mg})}\right] \times 100 \ldots
\end{aligned}
$$


Free and immobilized HRP activity determination using pyrogallol as a substrate

The activity of free and immobilized HRP was determined using pyrogallol as a standard substrate. Briefly, the assay solution consists of $1 \mathrm{ml}$ of pyrogallol $(0.013 \mathrm{M})$, $10 \mu \mathrm{l}$ hydrogen peroxide $(3 \% \mathrm{v} / \mathrm{v})$ and $10 \mu \mathrm{l}$ of the enzyme solution for free enzyme and $3 \mathrm{ml}$ of pyrogalol $(0.013 \mathrm{M}), 30 \mu \mathrm{l}$ hydrogen peroxide $(3 \% \mathrm{v} / \mathrm{v})$ and predetermined mass of immobilized biocatalyst for the immobilized HRP, respectively. The catalytic activity was monitored by following the change in absorbance at $420 \mathrm{~nm}$. For the immobilized HRP, the enzyme activity was determined as described above, after removing the immobilized enzyme by centrifugation (15 s at $5000 \mathrm{rpm}$ ). One unit of the activity was defined as the amount of peroxidase that will form $1.0 \mathrm{mg}$ of purpurogallin from pyrogallol in $20 \mathrm{~s}$ at $\mathrm{pH} 7.0$ and $20^{\circ} \mathrm{C}$. This unit is equivalent to $\sim 18 \mu \mathrm{M}$ per minute at $25^{\circ} \mathrm{C}$.

Optimal parameters determination for AV 109 dye oxidation using HRP-CLEAs

Optimal $\mathrm{pH}$, dye and $\mathrm{H}_{2} \mathrm{O}_{2}$ concentration in a batch reactor for the anthraquinone dye oxidation using immobilized HRP were determined. $\mathrm{pH}$ was examined by varying $\mathrm{pH}$ of the reaction mixture in the range 3-9. The glycine- $\mathrm{HCl}$ buffer was used for $\mathrm{pH} 3.0$; the sodium acetate buffer was used for 4.0-5.0, the sodium phosphate buffer for $\mathrm{pH} 8.0$ and glycine-NaOH buffer was used for $\mathrm{pH}$ 9.0. The influence of the dye and $\mathrm{H}_{2} \mathrm{O}_{2}$ concentration was examined by varying the initial concentrations in the range $\left(10-100 \mathrm{mg} \mathrm{l}^{-1}\right)$ and $(0.1-8 \mathrm{mM})$, respectively.

The oxidation was monitored by following the change in absorbance at $590 \mathrm{~nm}$ (Ultrospec 3300 pro, Amerischam Bioscience). The oxidation percentage was calculated by using the following mathematical expression [31]:

AV 109 dye oxidation, $\%=\frac{A_{0}-A_{t}}{A_{0}} \times 100$.

where $A_{0}$ is the initial absorbance of untreated dye solutions (control) and $A_{t}$ is the absorbance of dye solutions after the enzymatic treatment.

\section{Operational stability study}

Operational stability was examined under previously determined optimal conditions for AV 109 oxidation in a batch reactor. After applying HRP-CLEAs in the first AV 109 oxidation cycle, the immobilized preparation was removed using centrifuge (13000 rpm, $2 \mathrm{~min}$ ), rinsed with buffer (phosphate, $0.1 \mathrm{M}, \mathrm{pH} 7$ ) and applied in the next cycle. In addition, operational stability using pyrogallol as a substrate was examined. The cycles were repeated until the activity of HRP-CLEAs was detected.

\section{Results and discussion}

\section{CLEAs preparation}

First, a suitable precipitant must be selected for the HRP precipitation in physically formed aggregates. Protein denaturation occurs very often during the pre- cipitation, so it is necessary to examine the influence of precipitating agents and measure their effectiveness as retained activity of the formed aggregates. In order to retain as much of enzyme activity as it is possible, it is essential to precipitate the protein in its active conformation. As precipitating reagents, acetone, ammonium sulphate and 2-propanol were examined. In all experiments, enzyme-precipitant ratio was chosen to be $1: 3$, due to the maximum effectiveness of the examined precipitants achieved at this ratio (preliminary data, not shown). All experiments were performed at $4{ }^{\circ} \mathrm{C}$ in order to prevent enzyme denaturation. The obtained results are graphically presented in Figure 1.

Figure 1 clearly indicates that ammonium salt was the best option for the HRP precipitation. Using the $80 \%$ saturated ammonium sulphate, 15.4 and $54.1 \%$ of the activity was recovered and the aggregation yield was achieved, respectively. These results are expected due to the fact that HRP is mainly a hydrophilic enzyme and requires high amounts of ammonium sulphate for shielding charged groups in a HRP molecule, and thus HRP molecules form aggregates and precipitates [34].

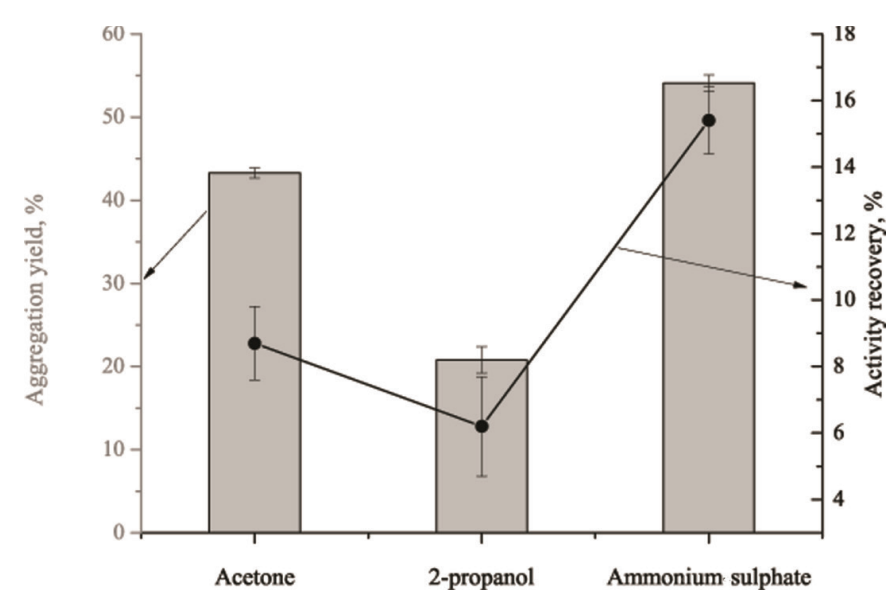

Figure 1. Precipitating reagent influence on the aggregation yield and the activity recovery of HRP-CLEEAs

The decrease of the activity recovery after precipitation with organic solvents is evident from Figure 1. The recovered activity after applying organic solvents, acetone and 2-propanol was 43.3 and $20.8 \%$, respectively. The decrease of the activity recovery can be interrelated with induced conformational changes during precipitation with organic solvents. During the organic solvents precipitation, water molecules essential for the catalytic activity are removed and solvent molecules penetrate into the enzyme structure, resulting in a less flexible protein structure and the activity decrease or complete denaturation [30]. HRP-CLEAs with the highest activity were obtained by using ammonium sulphate, and for further experiments ammonium salt $(80 \%)$ as precipitating reagent was used. HRP from a fresh horseradish extract precipitated with acetone gave the highest activity recovery in comparison with the preparations obtained by 
using the ammonium salt and 2-propanol. It is apparent that impurities from the fresh extract had a protecting role regarding the organic solvent influence on the recovered activity as it was shown in our previous study [31].

After precipitation, it is necessary to permanently link the obtained physical aggregates into insoluble form. Thereby, the following experiment in HRP immobilization in the form of CLEAs was to examine the influence of the initial glutaraldehyde concentration on performances of HRP-CLEAs. The activity recovery of CLEAs is greatly dependent on the glutaraldehyde concentration because of its size (small molecule) and reactivity, thus a detailed examination of its influence on the activity recovery will be carried out in the following step.

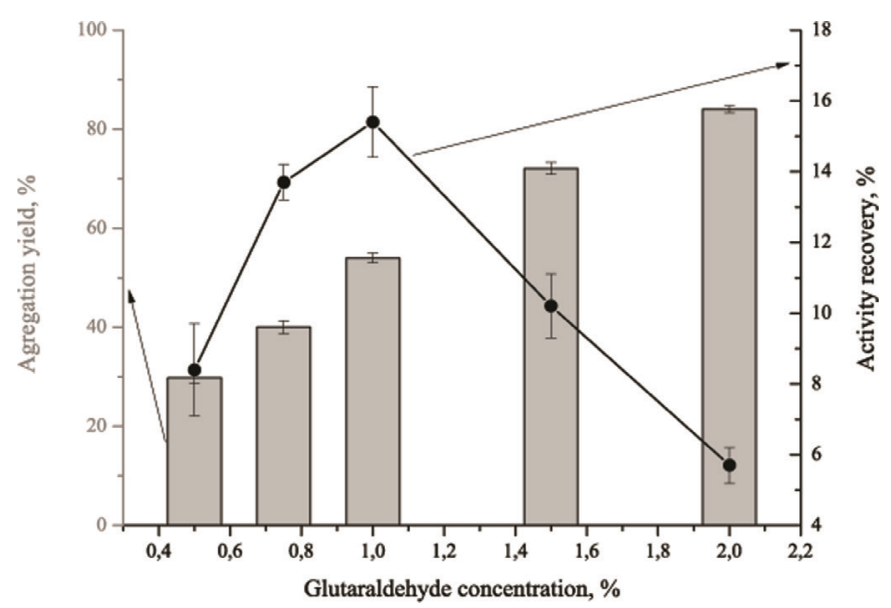

Figure 2. The initial glutaraldehyde concentration influence on the aggregation yield and the activity recovery of HRP-CLEAs

The increase in the glutaraldehyde concentration causes the increase in the aggregation yield and the decrease in the recovered activity. This phenomenon can be explained by the fact that the increase in the mass of cross-linked enzymes leads to greater steric hindrances, less flexibility and diffusion limitations. The obtained results are also in agreement with glutaraldehyde chemistry. Namely, high concentrations of glutaraldehyde can induce multipoint linkages between enzyme molecules and thus the enzyme activity can be reduced. Besides, glutaraldehyde molecules are small enough to penetrate into the enzyme structure, and cause important amino acid residues linking and loose of the enzyme catalytic function [35]. The initial glutaraldehyde concentration for the HRP from horseradish extract cross-linking was found to be $2 \%$ [31]. A possible explanation for this result is different sensitivity of commercial and peroxidase from the fresh horseradish extract. Apparently, impurities in the fresh extract had the protecting influence on HRP enzyme. The protecting influence could be explained as follows: 1) greater affinity of cross-linker towards impurities rather than HRP; 2) cross-linked impurities inside the core comprise HRP molecules avoiding the direct contact between the enzyme and the cross-linker and thus it is possible to apply higher initial glutaraldehyde concentrations during the immobilization. Even though glutaraldehyde can exert a negative influence on the enzyme, still it is the most widely used reagent for protein cross-linking. Recently, the data about cross-linking using oxidized polysaccharides like pectin, alginate, dextran, chitosan can be found in literature [35-37].

The next experiment was focused on the impact of BSA addition on the activity recovery and the aggregation yield of the obtained HRP-CLEAs. Inert proteins such BSA and the egg white are often added to the immobilization mixture in order to ensure enough free lysine groups required for obtaining stable aggregates. Schiff base is formed between the aldehyde group of cross-linking reagent and the amino group of lysine hence, for a good cross-linking, a sufficient number of available amino groups for bonding must exist. The results are presented in Figure 3.

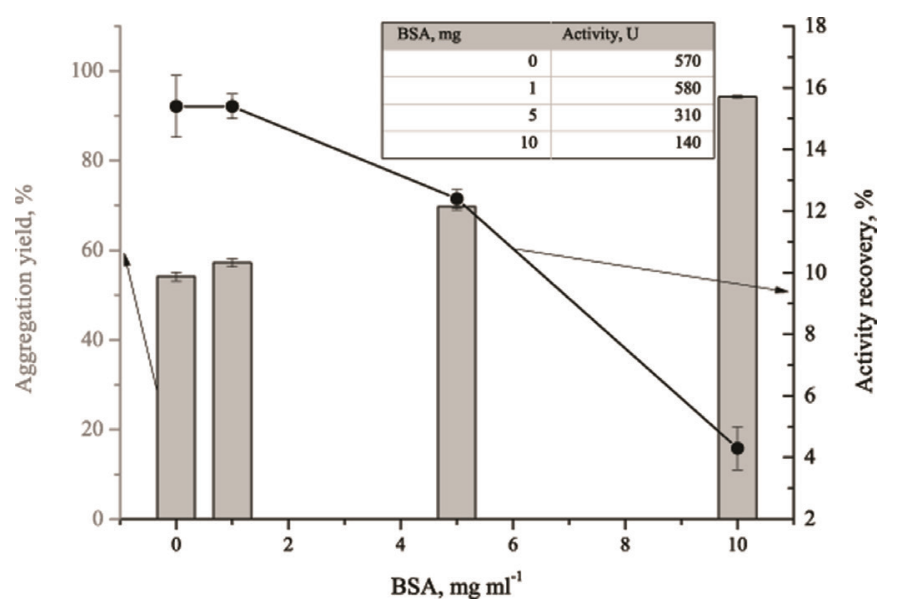

Figure 3. BSA influence on the aggregation yield and the activity recovery of HRP-CLEAs. Insert table: BSA influence on the activity $(\mathrm{U} g-1)$ of obtained HRP-CLEAs

The addition of BSA had a positive influence on both, the activity recovery and the aggregation yield until $5 \mathrm{mg}$ $\mathrm{ml}^{-1}$ of BSA was reached. Further increase in the BSA amount, beyond this optimal value, sharply declines the recovered activity meanwhile the aggregation yield is still trending upward. The BSA was the most studied inert protein in the CLEAs immobilization method. For instance, Torres et.al used the BSA for lipase CLEAs preparation [26]. The decrease in the retained activity with the increase in the BSA amount is often explained by mass transfer limitations. During the CLEAs preparation, HRP molecules can be accommodated inside the core formed by BSA molecules, thus the substrate penetration to the HRP active center is significantly hampered [31]. Besides, it is possible that the increase in the BSA amount increases the competition between BSA and HRP molecules, and the resulting CLEAs could contain less cross-linked HRP than BSA, thus the activity of the obtained CLEAs is significantly reduced. 

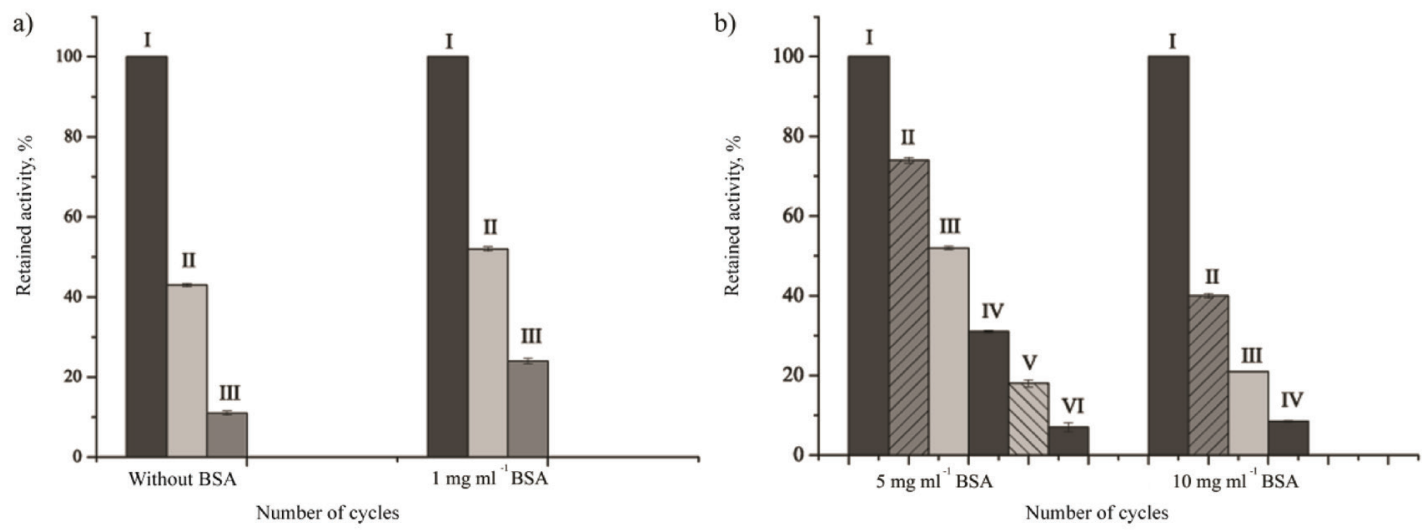

Figure 4. BSA influence on the operational stability of HRP-CLEAs.

Figure 4 shows the influence of the addition of BSA on the operational stability of HRP-CLEAs. It is evident that the addition of BSA has a positive influence on the operational stability of HRP-CLEAs. The increase in free Lys groups increases the number of cross-linked HRP molecules, resulting in the activity increase at the initial BSA concentration of $1 \mathrm{mg} \mathrm{ml}^{-1}$. The immobilized biocatalyst obtained under these conditions was possible to apply through three subsequent pyrogallol oxidation cycles. Further addition of BSA resulted in the activity decrease (insert Table, Figure 3) but the operational stability sharply increased. Namely, the obtained biocatalyst was applied in six consecutive cycles. The increase in the number of Lys groups increases the multipoint attachments between HRP-BSA molecules, cross-linked network stability, resulting in diffusion, mass transfer limitations and active center hindering [38]. The operational stability of CLEAs obtained from the fresh extract and commercial HRP differs substantially. Namely, the CLEAs of HRP from the horseradish extract was possible to apply through seven cycles of pyrogallol oxidation with $\sim 25 \%$ of retained activity. The CLEAs of commercial HRP was applied in six cycles with activity retention after the sixth cycle less than $10 \%$. The main explanation for this could be the physical form of obtained ag- gregations. Namely, the CLEAs from the fresh extract were larger, thinner, clearly interwoven and more solid particles, therefore less susceptible to hydration and breaking in the solution. On the other hand, CLEAs of commercial HRP were smaller, particles without apparent cross-linked structures that were extremely susceptible to dissolution and destruction. Disruption of CLEAs network may result in easier glutaraldehyde molecules penetration to the HRP active center and thus the activity decrease or inactivation.

In summary, optimal parameters for commercial HRP cross-linking are: precipitation using $80 \%$ ammonium sulphate, cross-linking with $1 \%$ of glutaraldehyde and BSA concentration $5 \mathrm{mg} \mathrm{m}^{\mathrm{l}-1}$.

Optimal conditions for AV 109 dye oxidation with HRP-CLEAs in a batch reactor examination

The effectiveness of HRP immobilized in the form of cross-linked enzyme aggregates towards anthraquinone, AV 109 dye oxidation was a further research step. The main parameters influencing the oxidation degree of $\mathrm{AV}$ 109 dye by HRP-CLEAs: $\mathrm{pH}$, dye and the hydrogen peroxide concentration were examined and the results are graphically presented in Figure 5.
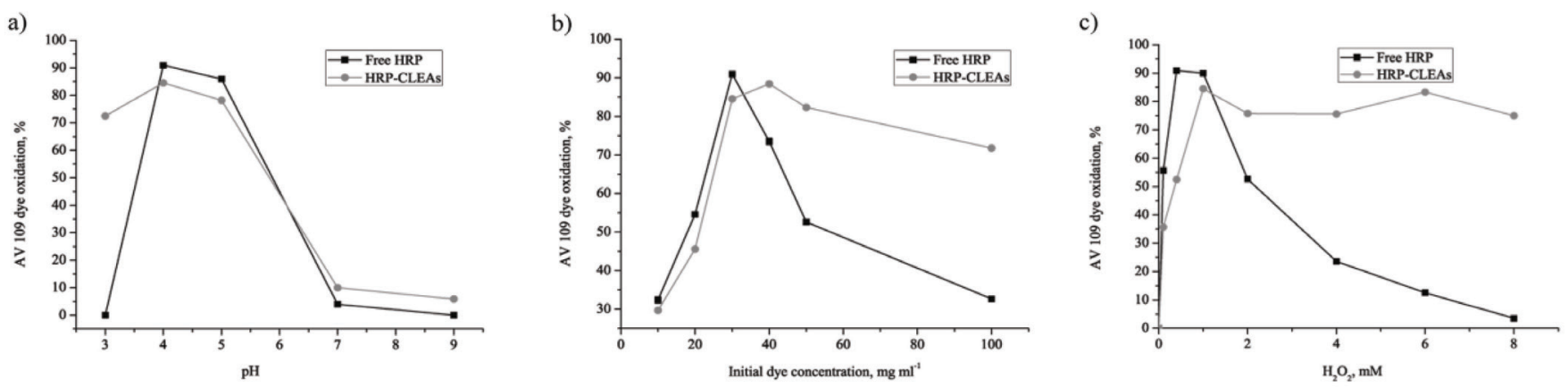

Figure 5. Initial a) $\mathrm{pH}$; b) dye and c) hydrogen peroxide concentration on the AV 109 dye oxidation catalyzed by free and HRP-CLEAs in a batch reactor.

As it can be seen in Figure 5 (a) $\mathrm{pH}$ is the parameter that affects the AV 109 dye oxidation most. Namely, the AV 109 dye oxidation increase in $\mathrm{pH}$ region 3-5 is evident from Figure 5 (a), where in the $\mathrm{pH}$ region 5-9 a sharp decrease can be observed. Compared with free HRP, crosslinked HRP appeared to be more efficient in the $\mathrm{pH}$ region 
3-5. $\mathrm{pH} 3$ proved to be the unfavorable environment for free HRP catalyzed oxidation of AV 109 dye, while HRPCLEAs oxidized $72.5 \%$ of the tested dye under the same $\mathrm{pH}$ conditions. The acidic environment is unfavorable for free HRP due to hydrogen bond network disrupting which protects the enzyme active center causing overexposure of the enzyme active center and activity loose [11]. On the other haand, cross-linking appeared to have a protecting effect on the HRP. Under acidic conditions, high AV 109 dye oxidation was achieved. The similar behavior was noticed in basic conditions, too. The highest activity of HRP-CLEAs in $\mathrm{pH} 4$ was achieved with total AV 109 dye oxidation of $84.5 \%$. For the further experiments, $\mathrm{pH}$ 4 was maintained as a constant parameter.

Figure 5 (b) shows the influence of the initial AV 109 dye concentration on the oxidizing capacity of HRPCLEAs. As it can be seen from Figure 5 (b) AV 109 dye exerts a stronger inhibitory influence on the free than on the cross-linked HRP. The increase in dye oxidation catalyzed by free HRP in the dye concentration range from $10-30 \mathrm{mg} \mathrm{l}^{-1}$ is evident, while a further increase in the initial dye concentration results in a sharp decline of AV 109 oxidation. AV 109 dye oxidation catalyzed by HRP is following the ping pong bi-bi kinetic model with substrate inhibition. The reason for lower AV 109 dye oxidation with the initial dye concentration increase is a result of the activity loose caused by the formation of inactive "dead-end" complex [7, 11]. In addition, very often the reaction products accumulation on the enzyme surface cause the obstacles in a substrate transfer to the enzyme active center reducing the productivity of the process [39]. Maximum oxidation of AV 109 dye 90.5\% catalyzed by free HRP at the initial dye concentration of $30 \mathrm{mg} \mathrm{l}^{-1}$ was achieved. Cross-linked laccase aggregates were applied for triphenylmethane and reactive dyes, and $60-70 \%$ of the dyes were removed [33]. On the other hand, cross-linked HRP was considerably more resistant towards the inhibitory influence of AV 109 dye. It is obvious from Figure 5 (b) that AV 109 oxidation of $88.4 \%$ under the initial dye concentration of $40 \mathrm{mg} \mathrm{l}^{-1}$ was achieved. Cross-linked HRP retained $81 \%$ of the initial activity at the initial dye concentration of $100 \mathrm{mg} \mathrm{l}^{-1}$. At the initial dye concentration of $100 \mathrm{mg} \mathrm{l}^{-1}$ the reaction was accomplished with a high oxidation degree of AV 109 dye of $71.8 \%$. Apparently, cross-linking contributed to the stability increase towards AV 109 substrate. Under the optimal dye concentration, $30 \mathrm{mg} \mathrm{l}^{-1}$ and $40 \mathrm{mg} \mathrm{l}^{-1}$, for free and HRPCLEAs, respectively, the influence of the initial hydrogen peroxide concentration was examined (Figure 5 (c)). A strong inhibitory influence of hydrogen peroxide on free HRP is evident from Figure 5 (c). The increase in the dye oxidation catalyzed by free HRP within the hydrogen peroxide concentration range $0-0.4 \mathrm{mM}$ is quite obvious from Figure 5 (c). A further increase in the hydrogen peroxide concentration above $0.4 \mathrm{mM}$ sharply decreases the oxidation degree of the tested dye [40]. Maximum AV 109 oxidation catalyzed by free HRP $90.5 \%$ at the initial hydrogen peroxide concentration of $0.4 \mathrm{mM}$ was achieved. In comparison with free HRP, cross-linked HRP was substantially more active in the broader range of hydrogen peroxide concentrations. Namely, the optimal hydrogen peroxide concentration for the reaction catalyzed by cross-linked HRP was $1 \mathrm{mM}$ with achieved AV 109 dye oxidation of $84.5 \%$. The increase in the initial hydrogen peroxide concentration up to $8 \mathrm{mM}$ lowered the AV 109 dye oxidation approximately $10 \%$ indicating that cross-linking had stabilizing and protecting effects on the HRP enzyme [32]. The affinity of immobilized commercial peroxidase and immobilized peroxidase from the fresh extract towards the tested dye differs significantly. The reaction mixture $\mathrm{pH}$ in both cases is similar. The inhibitory influence of the dye was less pronounced on CLEAs of commercial peroxidase, and the immobilized preparation showed the highest oxidation degree at the initial dye concentration $40 \mathrm{mg} \mathrm{l}^{-1}$, meanwhile a higher inhibitory influence of the initial dye concentration of $30 \mathrm{mg}$ $\mathrm{I}^{-1}$ was observed in the reaction catalyzed by CLEAs of peroxidase from the fresh horseradish extract. The lower CLEAs of peroxidase from the fresh extract activity could be the consequence of steric hindrances caused by impurities in the final immobilized preparation. Furthermore, the inhibitory influence of $\mathrm{H}_{2} \mathrm{O}_{2}$ was less pronounced in the case of commercial CLEAs catalyzed AV 109 dye oxidation. Finally, it can be concluded that commercial peroxidase immobilized in a form of CLEAs is a biocatalyst of improved performances compared to CLEAs of peroxidase from fresh horseradish extract. Both immobilized preparations have great applicative potential in the colored wastewaters treatment.

\section{Operational stability of HRP-CLEAs}

The increase in the number of the repeated use of the same immobilized biocatalyst significantly reduces the cost of the process catalyzed by expensive biocatalysts such as enzymes. Although immobilization frequently accompanies the enzyme activity loss, the increase in operational stability is the way to compensate the lost. Accordingly, besides high efficiency of HRP-CLEAs in AV 109 oxidation reaction confirmed above, it is necessary to examine the possibility of immobilized biocatalyst application in continuous systems through operational stability test. The operational stability was tested in the AV 109 dye and pyrogallol oxidation reaction and the results are presented in Figure 6.

It is evident from Figure 6 that considerably more stable HRP-CLEAs was in the pyrogallol oxidation reaction. Namely, five consecutive AV 109 oxidation reactions were performed using the HRP-CLEAs. After the fifth cycle, the residual activity was $\sim 10 \%$. On the other hand, pyrogallol seemed to be a less aggressive substrate for HRP-CLEAs. The obtained HRP-CLEAs were possible to apply through eight cycles, with $\sim 80 \%$ of retained activity. Comparing the structure of both substrates (Table 1 ), it is obvious that dye is a significantly greater molecule with fused aromatic rings. A possible reason for the HRP-CLEAs operational stability decrease in AV 109 
reaction is the large dye molecule accumulation across enzyme, as well as the steric hindrances which restrict the substrate approach to the enzyme active center. The same behavior is possible with AV 109 dye oxidation reaction products. Another reason for the operational stability decrease is mechanical instability of HRP-CLEAs. The pyrogallol oxidation reaction was performed in a small volume, $3 \mathrm{~mL}$ during $3 \mathrm{~min}$. The AV 109 dye oxida-

a)

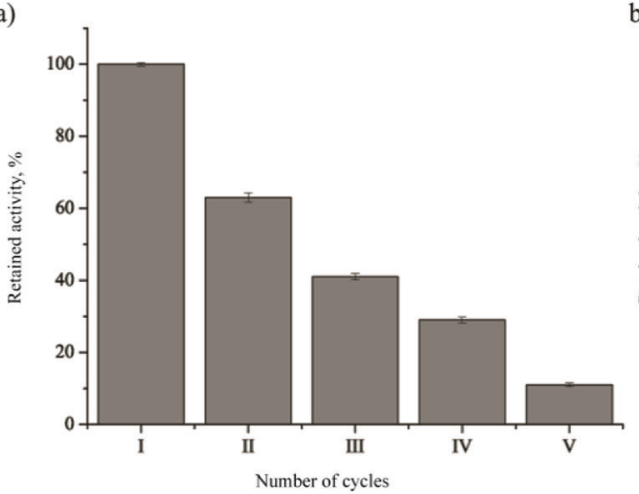

tion reaction was performed in $25 \mathrm{~mL}$ batch reactor during $40 \mathrm{~min}$. Under these conditions, a higher possibility of cross-linked proteins network hydration and disruptions exists and occurs. Comparing the data about operational stability with two different substrates it can be seen how the substrate structure influences the performances of the immobilized preparations.

Figure 6. Operational stability of HRP-CLEAs in a) AV 109 dye; b) pyrogallol oxidation.

Table 1. Chemical structure of AV 109 dye and pyrogallol

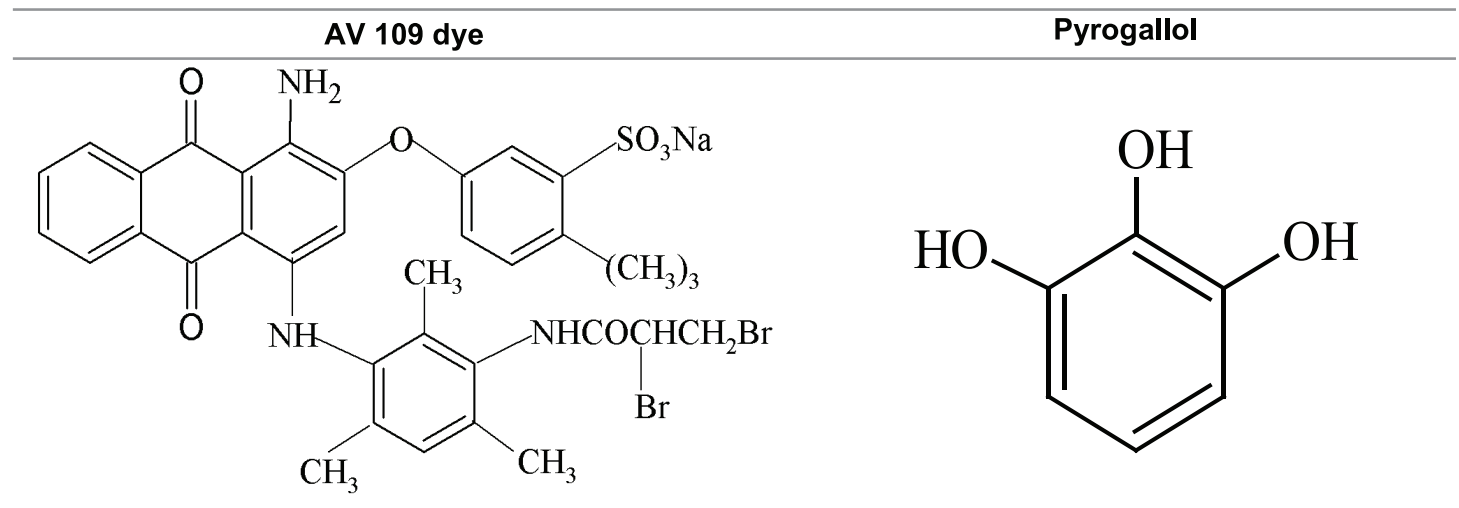

\section{Conclusion}

This paper reports the immobilized biocatalyst development of HRP. In the present study HRP-CLEAs demonstrated promising performances for the oxidation of anthraquinone class of dyes. A carrier-free immobilization technique appeared to be a good choice for HRP immobilization. Besides, the operational stability examined with two substrates proved to be at the extremely high level. Thus prepared biocatalyst with high operational stability and large amount of catalytically active mass obtained has great potential in the treatment of wastewaters colored with synthetic dyes. The CLEAs of peroxidase from fresh horseradish extract showed higher operational stability and a possibility of the application in a continuous recycled packed bed reactor. Besides, this immobilized preparation showed higher sensitivity towards the tested dye, as well as $\mathrm{H}_{2} \mathrm{O}_{2}$. Nonetheless, future work should be focused on the commercial per-

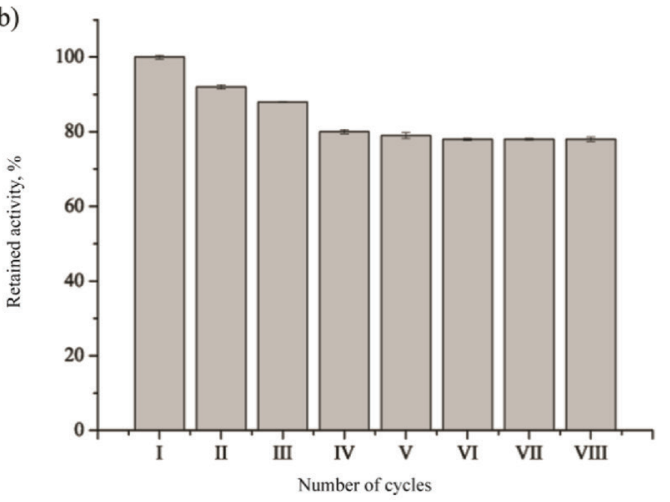


Journal of Medical Sciences, 30 (2000) 349-354.

[3] E. E. Ferapontova, V. G. Grigorenko, A. M. Egorov, P-chip and P-chip bienzyme electrodes based on recombinant forms of horseradish peroxidase immobilized on gold electrodes, Biochemistry, 66 (2001) 832-839.

[4] G. R. Lopes, D. C. G. A. Pinto, A. M. S. Silva, Horseradish peroxidase (HRP) as a tool in green chemistry, RSC Advances, 4 (2014) 37244-37265.

[5] J. Li, X. Zhao, Oxidative cross-linking of casein by horseradish peroxidase and its impact on emulsifying properties and the microstructure of acidified gel, African Journal of Biotechnology, 8 (2009) 5508-5515.

[6] J. Bucherit, D. E. Cura, H. Ma, C. Gasparetti, E. Monogioudi, G. Facco, M. Mattinen, H. Boer, R. Partanen, E. Selinheino, R. Lantto, K. Kruus, Crosslinking food proteins for improved functionality, Annual Review of Food Science and Technology, 1 (2010) 113-138.

[7] N. Ž. Šekuljica, N. Ž. Prlainović, J. R. Jovanović, A. B. Stefanović, V. R. Đokić, D. Ž. Mijin, Z. Knežević-Jugović, Immobilization of horseradish peroxidase onto kaolin, Bioprocess and Biosystems Engineering, 39 (2016) 461-472.

[8] Y. Morikawa, K. Shiomi, Y. Ishihara, N. Matsuura, Triple primary cancers involving kidney, urinary bladder, and liver in a dye worker, American Journal of Industrial Medicine, 31 (1997) 44-49.

[9] R. Nilsson, R. Nordlinder, U. Wass, B. Meding, L. Belin, Asthma, rhinitis, and dermatitis in workers exposed to reactive dyes, British Journal of Industrial Medicine, 50 (1993) 65-70.

[10] R. O. Alves de Lima, A. P. Bazo, D. M. Salvadori, D. Oliverira de Palma, G. De Araqao Umbuzeiro, Mutagenic and carcinogenic potential of a textile azo dye processing plant effluent that impacts a drinking water source, Mutation Research, 626 (2006) 53-60.

[11] N. Ž. Šekuljica, N. Ž. Prlainović, A.B. Stefanović, M. G. Žuža, D. Z. Čičkarić, D. Ž. Mijin, Z. D. Knežević-Jugović, Decolorization of anthraquinonic dyes from textile effluent using horseradish peroxidase: Optimization and kinetic study, The World Scientific Journal, vol. 2015, Article ID 371625, 12 pages.

[12] R. Xu, Y. Si, F. Li, B. Zhang, Enzymatic removal of paacetamol from aqueous phase: Horseradish peroxidase immobilized on nanofibrous membranes, Environmental Science and Pollution Research, 22 (2015) 3838-3846.

[13] W. Wang, Z. Li, W. Liu, J. Wu, Horseradish peroxidase immobilized on the silane-modified ceramics for the catalytic oxidation of simulated oily water, Separation and Purification Technology, 89 (2012) 206-211.

[14] M. Arslan, Immobilization horseradish peroxidase on amine-functionalized glycidyl methacrylate-gpoly(ethylene terephtalate) fibers for use in azo dye decolorization, Polymers Bulletin, 66 (2011) 865-879.

[15] J. Cheng, S. M. Yu, P. Zuo, Horseradish peroxidase immobilized on alluminium-pillared clay for the catalytic oxidation of phenolic wastewater, Water Research, 40 (2006) 283-290.

[16] N. Ž. Šekuljica, N. Ž. Prlainović, N. M. Lukić, A. M. Jakovljević, S. Ž. Grbavčić, D. Ž. Mijin, Z. D. KneževićJugović, Immobilization of peroxidase from fresh horseradish extract for anthraquinone dye decolorization, Zaštita materijala, 56 (2015) 335-339.

[17] Q. Chang, G. Jiang, H. Tang, N. Li, J. Huang, L. Wu, Enzymatic removal of chlorophenols using horeradish peroxidase immobilized on superparamagnetic Fe3O4/ graphene oxide nanocomposite, Chinese Journal of Catalysis, 36 (2015) 961-968.

[18] L. A. Dahili, I. K. Horvath, T. Feczko, 2,4-dichlorophenol removal by purified horseradish peroxidase enzyme and crude extract from horseradish peroxidase immobilized to nano spray dried ethyl cellulose particles, Process Biochemistry, 50 (2015) 1835-1842.

[19] R. Pramparo, F. Stuber, J. Font, A. Fortuny, A. Fabregat C. Bengoa, Immoblilisation of horseradish peroxidase on Eupergit $\circledast \mathrm{C}$ for the enzymatic elimination of phenol, Journal of Hazardous Materials, 177 (2010) 990-1000.

[20] X. Jiang, W. Tang, J. Gao, L. Zhou, Y. He, Immobilization of horseradish peroxidase in phospholipid-templatled titania and its application in phenolic compounds and dye removal, Enzyme and Microbial Technology, 55 (2014) $1-6$.

[21] G. Bayramoglu, M. Y. Arica, Enzymatic removal of phenol and $\mathrm{p}$-chlorophenol in enzyme reactor: Horseradish peroxidase immobilized on magnetic beads, Journal of Hazardous Materials, 156 (2008) 148-155.

[22] Z. Karim, R. Adnan, Q. Hussain, A $\beta$-cyclodextrin-chitosan complex as the immobilization matrix for horseradish peroxidase and its applicaion for the removal of azo dyes from textille effluent, International Biodeterioration and Biodegradation, 72 (2012) 10-17.

[23] S. Preethi, A. Anumary, M. Ashokkumar, P. Thanikaivelan, Probing horseradish peroxidase degradation of azo dyes from tannery wastewater, Springerplus, 2 (2013), 341.

[24] S. Khanahmadi, F. Yusof, A. Amid, S. S. Mahmod, M. K. Mahat, Optimized preparation and characterization of CLEA-lipase from cocoa pod husk, Journal of Biotechnology, 202 (2015) 153- 161.

[25] J. Cruz, O. Barbosa, R. C. Rodrigues, R. F. Lafuente, R. Torres, C. Ortiz, Optimized preparation of CALB-CLEAs by responce surface methodology: The necessity to employ a feeder to have an effective cross-linking, Journal of Molecular Catalysis B-Enzymatic, 80 (2012) 7-14.

[26] M. P. G. Torres, M. L. Foresti, M. L. Ferreira, CLEAs of Candida Antartica lipase B (CALB) with a bovine serum albumin (BSA) cofeeder core: Study of their catalytic activity, Biochemical Engineering Journal, 90 (2014) 36-43.

[27] S. Hama, S. Tamalampudi, A. Yoshida, N. Tamadani, N. Kuratani, H. Noda, H. Fukuda, A. Kondo, Enzymatic packed-bed reactor integrated with glycerol-separating system for solvent-free production of biodiesel fuel, Biochemical Engineering Journal, 55 (2011) 66-71.

[28] R. Taboada-Puig, C. Junghanns, P. Demarche, M. T. Moreira, G. Feijoo, J. M. Lema, S. N. Agathos, Combined cross-linked enzyme aggregates from versatile peroxidase and glucose oxidase: Production, partial characterization and application for the elimination of endocrine disruptors, Bioresource Technology, 102 (2011) 6593-6599.

[29] Y. Li, Z. Wang, X. Xu, L. Jin, A Ca-alginate particle coimmobilized with Phanerochaete cchrysosporium cells and the combined cross-linked enzyme aggregates from Trametes versicolor, Bioresource Technology, 198 (2015) 464-469.

[30] J. Yang, X. Xu, X. Yang, X. Ye, J. Lin, Cross-linked enzyme aggregates of Cerrena lacasse: Preparation enhanced $\mathrm{NaCl}$ tolerance and decolorization of Remazol Brilliant Blue Reactive, Journal of Taiwan Institute of Chemical Engineers, 56 (2016) 1-7.

[31] N. Ž. Šekuljica, N. Ž. Prlainović, S. M. Jakovetić, S. Ž. Grbavčić, N. D. Ognjanović, Z. D. Knežević-Jugović, D. 
Ž. Mijin, Removal of anthraquinone dye by cross-linked enzyme aggregates from fresh horseradish extract, Clean Soil Air Water, 44 (2016) 1-10.

[32] V. V. Kumar, S. Sivanesan, H. Cabana, Magnetic crosslinked laccase aggregates-Bioremediation tool for decolorization of distinct classes of recalcitrant dyes, Science of the Total Environment, 487 (2014) 830-839.

[33] V. V. Kumar, M. P. P. Kumar, K. V. Thiruvenkadaravi, P. S. Kumar, S.Sivanesan, Preparation and characterization of porous cross-linked laccase aggregates for the decolorization of thriphenyl and reactive dyes, Bioresource Technology, 119 (2012) 28-34.

[34] D. M. Vriezema, P. M. L. Garcia, N. S. Oltra, N. S. Hatzakis, S. M. Kuiper, R. J. M. Nolte, A. E. Rowan, J. C. M. van Hest, Positional assembly in polymersome nanoreactors for cascade reactions, Angewandte Chemie International Edition, 46 (2007) 7378-7382.

[35] S. S. Nadar, V. K. Rathod, Magnetic macromolecular cross linked enzyme aggregates (CLEAs) of glucoamylase, Enzyme and Microbial Technology, 83 (2016) 78-87.
[36] S. S. Nadar, V. K. Rathod, Magnetic macromolecular cross linked enzyme aggregates (CLEAs) of glucoamylase, Enzyme and Microbial Technology, 83 (2016) 78-87.

[37] A. Arsenault, H. Cabana, Laccase-based CLEAs: chitosan as a novel cross-linking agent, Journal of Enzyme Research, 2011 (2011) 1-10.

[38] S. S. Tukel, F. Hurrem, D. Yildrim, O. Alptekin, Preparation of Cross-Linked Enzyme Aggregates (CLEA) of Catalase and its Characterization, Journal of Molecular Catalysis B: Enzymatic, 97 (2013) 252-257.

[39] N. Ž. Šekuljica, N. Ž. Prlainović, J. R. Jovanović, A. B. Stefanović, S. Ž. Grbavčić, D. Ž. Mijin, Z. D. KneževićJugović, Immobilization of horseradish peroxidase by glutaraldehyde method and its application in decolorization of anthraquinone dye, Hemijska industrija, 70 (2016) 217-224

[40] F. Deyhimi, F. Nami, Peroxidase-Catalyzed Electrochemical Assay of Hydrogen Peroxide: A PingPong Mechanism, International Journal of Chemical Kinetics, 44 (2012) 699-704.

\section{Izvod \\ OKSIDACIJA ANTRAHINONSKIH BOJA PEROKSIDAZOM IZ RENA IMOBILISANOM U OBLIKU UMREŽENIH ENZIMSKIH AGREGATA}

Nataša Ž. Šekuljica ${ }^{1}$, Nevena Ž. Prlainović ${ }^{1}$, Andrea B. Stefanović2 ${ }^{2}$ Jelena R. Jovanović ${ }^{2}$ Sonja M. Jakovetić ${ }^{2}$, Zorica D. Knežević-Jugović², Dušan Ž. Mijin²

1Univerzitet u Beogradu, Inovacioni centar, Tehnološko-metalurški fakultet Beograd, Beograd, Srbija

2Univerzitet u Beogradu, Tehnološko-metalurški fakultet Beograd, Beograd, Srbija

Pronalazak održivih i ekološki prihvatljivih metoda za uklanjanje sintetičkih boja je jedan od vodećih izazova za istraživače. $U$ ovom radu akcenat je na metodi imobilizacije bez primene nosača. Imobilisani preparat peroksidaze iz rena, aktivnosti $580 \mathrm{U} \mathrm{g}^{-1}$ dobijen je pod sledećim uslovima imobilizacije: taložni reagens $80 \%$ amonijum-sulfat, umrežavajući reagens $1 \%$ glutaraldehid i goveđi serum albumin koncentracije $5 \mathrm{mg} \mathrm{ml}^{-1}$. Dobijeni umreženi agregat peroksidaze iz rena pokazao je veliki afinitet prema model antrahinonskoj boji, C. I. AV 109. Pod optimalnim uslovima: pH 4, koncentracija boje $40 \mathrm{mg} \mathrm{l}^{-1}$, koncentracija $\mathrm{H}_{2} \mathrm{O}_{2}$ i $0,1 \mathrm{U}$ enzimske aktivnosti oksidovano je $88,4 \%$ ispitivane boje. Mogućnost primene imobilisanog enzima kroz pet i osam uzastopnih ciklusa oksidacije boje i pirogalola (zadržana aktivnost $~ 80 \%$ ) pokazuje da je imobilisani enzim efikasan i ekološki prihvatljiv biokatalizator koji se može koristiti u oksidaciji aromatičnih jedinjenja iz otpadnih voda. Ovaj rad predstavlja nastavak istraživanja vezanog za umrežavanje peroksidaze iz svežeg ekstrakta rena, koja se takođe pokazala kao imobilisani biokatalizator sa velikim potencijalom primene u tretmanu obojenih otpadnih voda.
(ORIGINALNI NAUČNI RAD) UDK 577.152.3:66.098:667.283.6

Ključne reči: peroksidaza iz rena, imobilizacija, umreženi enzimski agregati, antrahinonske boje, otpadne vode 